\title{
DEVELOPING THE MATERIAL-SERVICE SYSTEM CONCEPT: A CASE STUDY OF STEEL INDUSTRIAL DRUMS
}

\author{
Engelmann, Anais (1); \\ Zeeuw van der Laan, Anouk (1); \\ Aid, Graham (2); \\ Nybom, Lars (2); \\ Aurisicchio, Marco (1) \\ 1: Imperial College London; \\ 2: Ragn-Sells Group
}

\begin{abstract}
Within the circular economy, the Product-Service System (PSS) is a key business model to slow down and dematerialise resource consumption between manufacturers or service providers and customers. Material-Service Systems (MSSs) have been proposed as a business model to develop the performance economy focusing on the relationship between material suppliers and manufacturers. The aim of this research is to introduce and develop the MSS concept and to apply it to a real-world case study. The research involved two stages. First, a modelling method is proposed to represent the flow, transformation and ownership of resources by the stakeholders in a supply chain. Second, the method is tested using steel industrial drums as a case. The results indicate that the MSS has the potential to radically transform the steel drums industry and it could work effectively with a PSS within a reuse system to recondition and reintroduce obsolete drums into the market.
\end{abstract}

Keywords: Product-Service Systems (PSS), Sustainability, Circular economy

\author{
Contact: \\ Aurisicchio, Marco \\ Imperial College London \\ Dyson School of Design Engineering \\ United Kingdom \\ m.aurisicchio@imperial.ac.uk
}

Cite this article: Engelmann, A., Zeeuw van der Laan, A., Aid, G., Nybom, L., Aurisicchio, M. (2021) 'Developing the Material-Service System Concept: A Case Study of Steel Industrial Drums', in Proceedings of the International Conference on Engineering Design (ICED21), Gothenburg, Sweden, 16-20 August 2021. DOI:10.1017/pds.2021.122 


\section{INTRODUCTION}

Since it first emerged in the 1970s, the circular economy (CE) has exponentially gained momentum (EMF, 2012). In an attempt to decouple economic activity from the consumption of finite resources, companies are increasingly shifting towards business models that extract maximum value from existing resources and eliminate waste, such as through PSSs (EMF, 2020). They are also striving to manage resources, i.e. materials, components and products, in circular flows (Stahel, 2019a; Stahel, 2019b). However, despite an increased shift towards services and a focus on circular flows, current implementations of the CE are still inefficient for a variety of reasons. These include inherent process losses, a lack of financial incentives and profitability, limited availability of materials for circulation and growing material demand (van Ewijk, 2018). These inefficiencies can be in part addressed by rethinking the management of resources in supply chains, exploring business models that sit upstream of PSSs and integrating the operations of stakeholders.

Centralising resource ownership and providing resources as a service has the potential to shift us faster towards the performance economy (PE) and close loops in supply chains. Various types of service systems have been proposed across industry sectors and developed to address these issues. As an example the MSS is a business model in which material suppliers provide materials as a service to manufacturers (Aurisicchio et al., 2020). Nevertheless, current service systems proposals are still conceptual, knowledge is fragmented and there is a lack of contextualisation between the models and the overall supply chain.

This paper brings together existing literature on service systems to review proposed concepts, identify where different service systems sit along the supply chain and how they can work together. After this initial framing, the paper explores how to implement the MSS between a material supplier and a product manufacturer, as well as the transformations needed to deploy the business model in a supply chain. A case study focusing on steel industrial drums is used to understand how stakeholders in the supply chain would exchange resources, who owns what, and how the resources would flow in the forward and reverse supply chain.

\section{LITERATURE REVIEW}

\subsection{The Performance Economy and Product-Service Systems}

Servitisation of goods (i.e. resources in the form of material, component or product) is a concept that has become popular through Walter Stahel's work on the performance economy (PE) (Stahel, 2019b). It refers to selling the performance of goods rather than the goods themselves for the purpose of dematerialising the consumption of resources (Stahel, 2010). In this conception, ownership and the liability of goods are retained by the actors in the supply chain concerned with production activities. Retaining ownership of goods is beneficial to incentivise producers to prevent losses and waste over the full service life of objects (Torres de Miranda Pinto, 2019b) and can benefit different service systems. The most widely advocated service system is the PSS (Tukker, 2004), where instead of buying a product, customers purchase its service and the product manufacturer retains ownership (Blomsma et al., 2018). Examples include companies such as ZipCar offering car rentals and Philips' 'Pay-per-lux' offering lighting as a service. In service systems, the shift in thinking from flow to stock optimisation allows for a change in the relationship between stakeholders. Where revenue was previously linked to resource consumption, there is now the opportunity to link it to the use and recirculation of materials and products (Stahel, 2019b). There are, however, significant barriers to the adoption of the PE, e.g. current business models focus on flows rather than prioritising the quality, value and use of stocks and public policy subsidises the use of non-renewable resources rather than taxing it (Stahel et al., 2016).

\subsection{Service systems beyond PSSs}

The PE has been explored in the context of different industry sectors and resource types. The concept, indeed, can be extended from selling the performance of products to that of upstream resources in different states such as components and materials. Table 1 presents examples of different service systems organised in the order of their chronological emergence in the literature. The examples include both theoretical concepts of service systems (e.g. PSS, Licence to Mine, MSS) as well as applications of the services (e.g. Chemical Leasing, Steel as a Service). They also show that services exist across a broad spectrum of resource aggregation levels including PSSs, Component-Service Systems (CSS) and MSSs (Blomsma et al., 2020b). The remainder of this section introduces examples of service systems beyond the PSS. 
Chemical Leasing, or Chemical Management Services, has been fostered by the United Nations Industrial Development Organisation (UNIDO) since 2004 (UNIDO, 2020). Chemical Leasing emerged as a business concept in the industry prior to the generic theory. It has been described as an example of a PSS (UNEP, 2015) in which service providers charge customers monthly or yearly fees for handling chemical substances as well as a form of business activity within the PE framework (Stahel et al, 2016). In this interpretation, a chemical is seen as a product rather than a material, and it is worth noting that contrary to a traditional PSS, only the unused product is returned (Stoughton et al, 2003). The primary purpose of the Chemical Leasing model is to align the incentives of both the service provider and buyer to reduce life cycle costs.

Licence to Mine, having also emerged independently of any generalised service system theory, is where mining corporations lease mined resources for a certain period of time and eventually have to return them to their countries of origin (Hagan et al, 2019). According to its proponents, a failure to return the resources (i.e. a removal of the asset from the country of origin), should lead to purchase at a premium price. As a form of service system, it falls upstream of PSSs because the leasing transactions begin when the resource is raw and involve the extraction of unprocessed materials, as opposed to beginning with the material supplier leasing a ready-for-manufacture material to a producer. It is, therefore, an example of a system focussed on offering raw material services. It is worth noting that the Licence to Mine model has not been fully conceptualised, and there is a need to further explore relations between nation-states and corporations, as well as the effect of retaining resource wealth in the country of origin for successful implementation. The large-scale nature of the model and the global cooperation between governments, which is necessary for this proposal, are its greatest barriers to entry. The World Trade Organisation has been suggested as a suitable candidate for enforcing this model (Hagan et al., 2019) but further development is required. Stahel names the UN Mercury agreement as a possible contender for the first implementation of this system as a way of combating mercury pollution through supply chain management (Stahel, 2019b).

Steel as a Service is an early-stage concept for a business model under which steel is servitised (Ness et al., 2015) as either a CSS or a PSS.

MSS is a general business model in which material suppliers offer producers the use of materials through services while retaining ownership throughout the supply chain (Aurisicchio et al., 2020). The retention of ownership by material suppliers creates a shift from traditional ownership transaction models to leasing and pay-per-use models, similar to PSSs, with the aim of improving resource efficiency by controlling the flow of resources in the entire supply chain. However, there is still much to be understood about MSSs before they can be adopted and implemented in modern supply chains. Challenges to this model include (but are not limited to) identifying suitable materials, determining the technologies needed to sort, separate, purify and identify materials, understanding the environmental impact of material recovery, investigating the dependency of the business model on PSSs and consumer behaviour, assessing the general viability of the business model and establishing the likelihood of changing the current state of affairs (Aurisicchio et al., 2020).

\subsection{Meaning and implications of ownership in service systems}

The service systems in Table 1 use ownership of resources in different ways and for different purposes. Ownership is a familiar concept in the service systems literature as it is used to describe business models and the roles of stakeholders. For example, retained or centralised ownership is when the supplier keeps ownership of multiple products while they are independently in possession of the customers (Stahel, 2019a; Zeeuw van der Laan et al., 2020); psychological ownership is when a customer perceives to be the owner of a resource (Baxter and Aurisicchio, 2018); maintained ownership is when the supplier retains ownership of products but is also responsible for maintaining them while they are in the possession of the customers (Stahel, 2019b); and state ownership is when materials, components or products are owned by the public sector, such as a nation-state or local government, as opposed to being owned by a private company or supplier (Hagan et al., 2019). Further, it is acknowledged that responsibilities and liabilities for resources can change between life cycle phases (Stark, 2011). Nevertheless, and to the best of our knowledge, an ontology of types of ownership and how they are divided over different stakeholders does not exist. Different types of ownership in different moments are merely a notion in the literature and there is limited understanding of the changes in ownership in relation to, and as a consequence of, the transformation of resources. 
Table 1. Service systems

\begin{tabular}{|c|c|c|c|c|c|}
\hline $\begin{array}{l}\text { Service } \\
\text { system }\end{array}$ & $\begin{array}{l}\text { Owner/ } \\
\text { Customer }\end{array}$ & $\begin{array}{l}\text { Value } \\
\text { proposition }\end{array}$ & $\begin{array}{l}\text { Resource state/ } \\
\text { characteristics }\end{array}$ & Success factors & Barriers \\
\hline $\begin{array}{l}(1990) \\
\text { Product } \\
\text { Service } \\
\text { System } \\
\text { (PSS) }\end{array}$ & $\begin{array}{l}\text { Product } \\
\text { manufactu } \\
\text { rers/ } \\
\text { Consumers }\end{array}$ & $\begin{array}{l}\text { - Leasing of } \\
\text { products } \\
\text { - Performance } \\
\text { of products }\end{array}$ & $\begin{array}{l}\text { Product } \\
\text { - Products with } \\
\text { appeal }\end{array}$ & $\begin{array}{l}\text { - Incentivises resource } \\
\text { efficiency for the } \\
\text { owner through product } \\
\text { durability }\end{array}$ & $\begin{array}{l}\text { - Requires } \\
\text { cultural shift } \\
\text { of customers. } \\
\text { - Risk of long- } \\
\text { term contracts }\end{array}$ \\
\hline $\begin{array}{l}(2000) \\
\text { Chemic } \\
\text { al } \\
\text { Leasing } \\
\text { (type of } \\
\text { PSS) }\end{array}$ & $\begin{array}{l}\text { Chemical } \\
\text { supplier/ } \\
\text { Customer }\end{array}$ & $\begin{array}{l}\text { - Performance } \\
\text { of chemicals } \\
\text { - Waste } \\
\text { management } \\
\text { practices (i.e. } \\
\text { chemical waste } \\
\text { can be } \\
\text { returned) }\end{array}$ & $\begin{array}{l}\text { Component/ } \\
\text { Material } \\
\text { - Easy to } \\
\text { recover } \\
\text { chemicals } \\
\text { - High } \\
\text { recovery rate } \\
\text { - E.g. solvents } \\
\text { and catalysts }\end{array}$ & $\begin{array}{l}\text { - Improves the } \\
\text { customer's economic } \\
\text { and environmental } \\
\text { performance } \\
\text { - Incentivises resource } \\
\text { efficiency and } \\
\text { innovation for the } \\
\text { owner through } \\
\text { performance delivery }\end{array}$ & $\begin{array}{l}\text { - Lack of } \\
\text { customer } \\
\text { demand } \\
\text { - Strict } \\
\text { legislation } \\
\text { - Requires } \\
\text { investment by } \\
\text { the owner. }\end{array}$ \\
\hline $\begin{array}{l}(2008) \\
\text { Licence } \\
\text { to Mine } \\
\text { (raw } \\
\text { MSS) }\end{array}$ & $\begin{array}{l}\text { Nation- } \\
\text { states/ } \\
\text { Mining } \\
\text { corporatio } \\
\mathrm{n}\end{array}$ & $\begin{array}{l}\text { - Leasing of } \\
\text { mined raw } \\
\text { materials } \\
\text { - State retains } \\
\text { value of mined } \\
\text { materials }\end{array}$ & $\begin{array}{l}\text { Material } \\
\text { - Minerals and } \\
\text { metals in raw } \\
\text { state }\end{array}$ & $\begin{array}{l}\text { - Continued benefits } \\
\text { from value generated } \\
\text { over resource for } \\
\text { owner. } \\
\text { - Incentivises customer } \\
\text { to recycle resources }\end{array}$ & $\begin{array}{l}- \text { Complex to } \\
\text { scale } \\
- \text { Requires } \\
\text { monitoring, } \\
\text { enforcement } \\
\text { and regulation }\end{array}$ \\
\hline $\begin{array}{l}(2014- \\
16) \\
\text { Steel as } \\
\text { a } \\
\text { Service } \\
\text { (CSS) }\end{array}$ & $\begin{array}{l}\text { Steel } \\
\text { supplier/ } \\
\text { Constructi } \\
\text { on industry }\end{array}$ & $\begin{array}{l}\text { - Sharing and } \\
\text { circulation of } \\
\text { steel } \\
\text { components/ } \\
\text { products } \\
\text { between } \\
\text { construction } \\
\text { sites }\end{array}$ & $\begin{array}{l}\text { Product/ } \\
\text { Component } \\
\text { - Structural } \\
\text { steel widely } \\
\text { used in } \\
\text { construction } \\
\text { industry } \\
\text { - Standardised } \\
\text { components to } \\
\text { use in multiple } \\
\text { scenarios } \\
\text { - Equipped } \\
\text { with tracking } \\
\text { technology }\end{array}$ & $\begin{array}{l}\text { - Incentivises resource } \\
\text { efficiency through } \\
\text { product durability } \\
\text { - Provides new } \\
\text { business opportunities } \\
\text { for the owner through } \\
\text { secondary resource/ } \\
\text { extending product } \\
\text { lifetime } \\
\text { - Provides a new } \\
\text { business opportunity } \\
\text { for the owner through } \\
\text { life cycle information } \\
\text { services }\end{array}$ & $\begin{array}{l}\text { - Lack of real } \\
\text { life data to } \\
\text { facilitate } \\
\text { modelling } \\
\text { - Requires } \\
\text { testing of data } \\
\text { collection } \\
\text { technology } \\
\text { - Risk of } \\
\text { resource } \\
\text { performance } \\
\text { degradation }\end{array}$ \\
\hline $\begin{array}{l}\text { (2019) } \\
\text { Material } \\
\text { Service } \\
\text { System } \\
\text { (MSS) }\end{array}$ & $\begin{array}{l}\text { Material } \\
\text { suppliers/ } \\
\text { Product } \\
\text { manufactu } \\
\text { rers }\end{array}$ & $\begin{array}{l}- \text { Leasing of } \\
\text { materials } \\
\text { - Returning to } \\
\text { supplier for } \\
\text { recovery, } \\
\text { regeneration or } \\
\text { waste } \\
\text { management }\end{array}$ & $\begin{array}{l}\text { Component/ } \\
\text { Material } \\
\text { - Market-ready } \\
\text { materials (i.e. } \\
\text { raw materials } \\
\text { that are } \\
\text { processed and } \\
\text { ready for } \\
\text { manufacturing) }\end{array}$ & $\begin{array}{l}\text { - Incentivises resource } \\
\text { efficiency for the } \\
\text { owner through } \\
\text { resource ownership } \\
\text { - Prevents waste and } \\
\text { leakage through } \\
\text { increased control over } \\
\text { resource flows } \\
\text { - Reduces dependency } \\
\text { on virgin resources and } \\
\text { closes the loop }\end{array}$ & $\begin{array}{l}\text { - Undefined } \\
\text { suitability of } \\
\text { resources } \\
\text { - Risk of } \\
\text { resource } \\
\text { performance } \\
\text { degradation } \\
\text { - Requires } \\
\text { cultural shift } \\
\text { of customers }\end{array}$ \\
\hline
\end{tabular}




\section{RESEARCH METHODOLOGY}

In this research, a method is initially developed to model the flow, transformation and ownership of resources in a supply chain. A case study is then selected and used to test the modelling method.

\subsection{Modelling method}

Current CE models, such as the Butterfly Diagram (EMF, 2020), capture the flow of materials, nutrients, components and products showing high-level strategies. In industrial ecology, the Material Flow Analysis diagram is a method to model the flows and stocks of materials using symbols such as processes, stocks, flows and system boundaries (Brunner et al., 2004). Neither of these models, however, concurrently capture resource states, resource processing activities, business activities and resource ownership shifts. This is valuable information to analyse the sustainability of a resource flow and define the business model along with the contractual agreements between stakeholders.

Therefore, a diagrammatic method was developed to model the flow, transformation and ownership of resources in a supply chain operating with the MSS and within a PE (see Figure 1). The nodes of the diagram represent resource states, grouped by following the Resource States framework (Blomsma et al, 2020a) and qualified through stakeholders (see Table 2). The nodes are linked through arcs with labels to represent either resource processing activities or business activities (see Table 2). Each node is further qualified by stating which stakeholder has which type of ownership. Due to the lack of a comprehensive ownership ontology, we defined four types of ownership to refine the meaning of the resource as an asset to the different stakeholders and characterise the business models. These are: material ownership, value ownership, right-to-use ownership and psychological ownership.

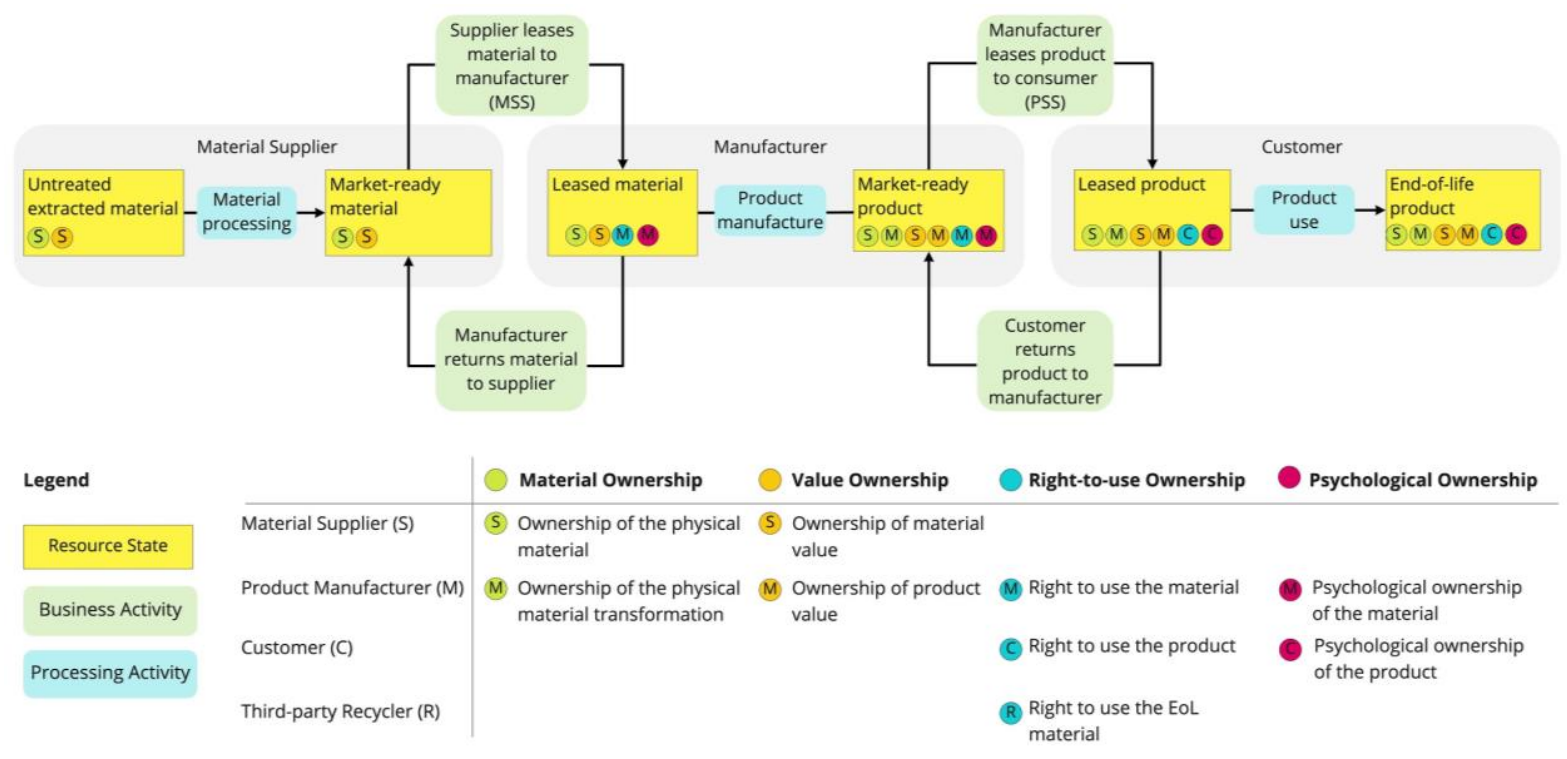

Figure 1. Modelling method.

\subsection{Case study: steel industrial drums}

A case study of steel drums is used to explore the proposed MSS business model. The case study introduces a supply chain in which steel is transformed into drums and stakeholders do business using both the MSS and the PSS. The supply chain presented in the case study includes both features of existing supply chains such as reusable drums offered with a PSS (i.e. reconditioning services) and hypothetical features such as the MSS and its reverse logistics. Notably, the hypothetical features are due to the fact that at present, the MSS is a conceptual model. Steel and industrial drums were selected as the subject of the case study to control the problem complexity.

Steel is a material with high recovery rates. Cycling steel can cause the material to lose its properties and performance due to the mixing of different alloys. Despite being one of the world's most widely recycled products, the continuous growth of the industry prevents the demand for steel from being met through the recycling of end-of-life products alone (WSA, 2015). In the European industry, steel recovered from products is more likely to be sold in other markets than to go back into the original supply chains. This highlights the problem of functional value retention and raises the question of 
whether higher levels of integration in supply chains can make it easier to recover steel via reverse logistics (Torres de Miranda Pinto, 2019a). More value could be retained, for example, if manufacturers were able to track steel alloys, which would lower the need to adjust element proportions as is often necessary with scrap steel. The steel industry could, therefore, benefit from service systems such as the MSS that focus on managing forward and reverse logistics as well as keeping the material within supply chains to achieve improved levels of circularity.

In the industrial packaging sector, drums used for the storage and transportation of both hazardous and non-hazardous materials are a growing market, with the steel drums segment expected to hold the major market share followed by the polymer drums segment (IPA, 2020). Industrial drums have a rapid turnaround time between the manufacturer and customer and are typically reused. In the reuse system, durable drums are reconditioned through chemical cleaning in accordance with the UN's legal and safety requirements for industrial packaging of dangerous goods. Two existing types of reuse configurations have been identified. The first is where manufacturers take a total drum management approach by offering reconditioning and waste management services to their customers and can therefore manage the drums throughout their entire product life cycle. The second is where a thirdparty company offers reconditioning services either as a licensed agent through the manufacturer, or a separate, external company. Data on the life cycle of durable steel drum systems in Europe finds that the typical average number of trips ranges from 3.6 to 8.7, depending on whether it is an open-head or tight-head drum and the rim thickness (Manuilova, 2003). A reuse system is advantageous for the implementation of the MSS, as the collection of used drums would facilitate the reverse logistics of returning the steel to the material supplier. Currently, empty steel drums that have reached the end of their life cycle and can no longer be reconditioned are sanitised prior to being sent off for recycling. Applying the MSS would mean that these end-of-life drums are returned to the supplier instead of being scrapped (i.e. managed by a recycler as part of heterogeneous flows), thereby allowing the steel to be reintegrated into the same supply chain and improving recovery rates. In conclusion, the versatility and recyclability of steel combined with the reuse practice of industrial drums were found to provide an interesting case for the application of the MSS.

Table 2. Elements of the modelling method

\begin{tabular}{|l|l|l|}
\hline \multicolumn{2}{|l|}{ Elements } & Categories \\
\hline Node & $\begin{array}{l}\text { Resource } \\
\text { state }\end{array}$ & $\begin{array}{l}\text { Particles, i.e. raw material, untreated extracted material; parts, i.e. treated } \\
\text { material, manufacture-ready material, component; and products, i.e. } \\
\text { assembled product, end-of-life product. }\end{array}$ \\
\cline { 2 - 3 } $\begin{array}{l}\text { Node } \\
\text { qualifier }\end{array}$ & Stakeholder & $\begin{array}{l}\text { Material supplier (S); product manufacturer (M); customer (C); third- } \\
\text { party recycler (R). }\end{array}$ \\
\hline $\begin{array}{l}\text { Ownership } \\
\text { Arc } \\
\text { label }\end{array}$ & $\begin{array}{l}\text { Material, i.e. ownership of the physical material and its liabilities, } \\
\text { ownership of the physical material transformation and its liabilities; value, } \\
\text { i.e. ownership of the material market value, ownership of the leasable } \\
\text { material value and ownership of the product value (i.e. value added); right } \\
\text { to use, i.e. authorised ownership to use the material (i.e. transform the } \\
\text { material), authorised ownership to grant access to or use the product, and } \\
\text { authorised ownership to use the EoL material; psychological, i.e. } \\
\text { perceived ownership of the material or product. }\end{array}$ \\
\cline { 2 - 4 } & $\begin{array}{l}\text { Processing } \\
\text { activity } \\
\text { activity }\end{array}$ & $\begin{array}{l}\text { Activities to transform the state of a resource, i.e. extraction of virgin } \\
\text { materials, mechanical/chemical disaggregation of materials, processing } \\
\text { and shaping of the treated material, part manufacturing, assembly of } \\
\text { components, distribution, disassembly and recovery. }\end{array}$ \\
\hline $\begin{array}{l}\text { Activities that describe the exchange of value between stakeholders, i.e. } \\
\text { Material-Service System, Component-Service System, Product-Service } \\
\text { System. }\end{array}$ \\
\hline
\end{tabular}




\section{RESULTS}

This section shows how the supply chain for a resource could be adapted to include the MSS business model in which a supplier leases materials to a manufacturer. Steel drums are used as a case study to discuss how three configurations of the supply chain would practically work (see Figure 2).

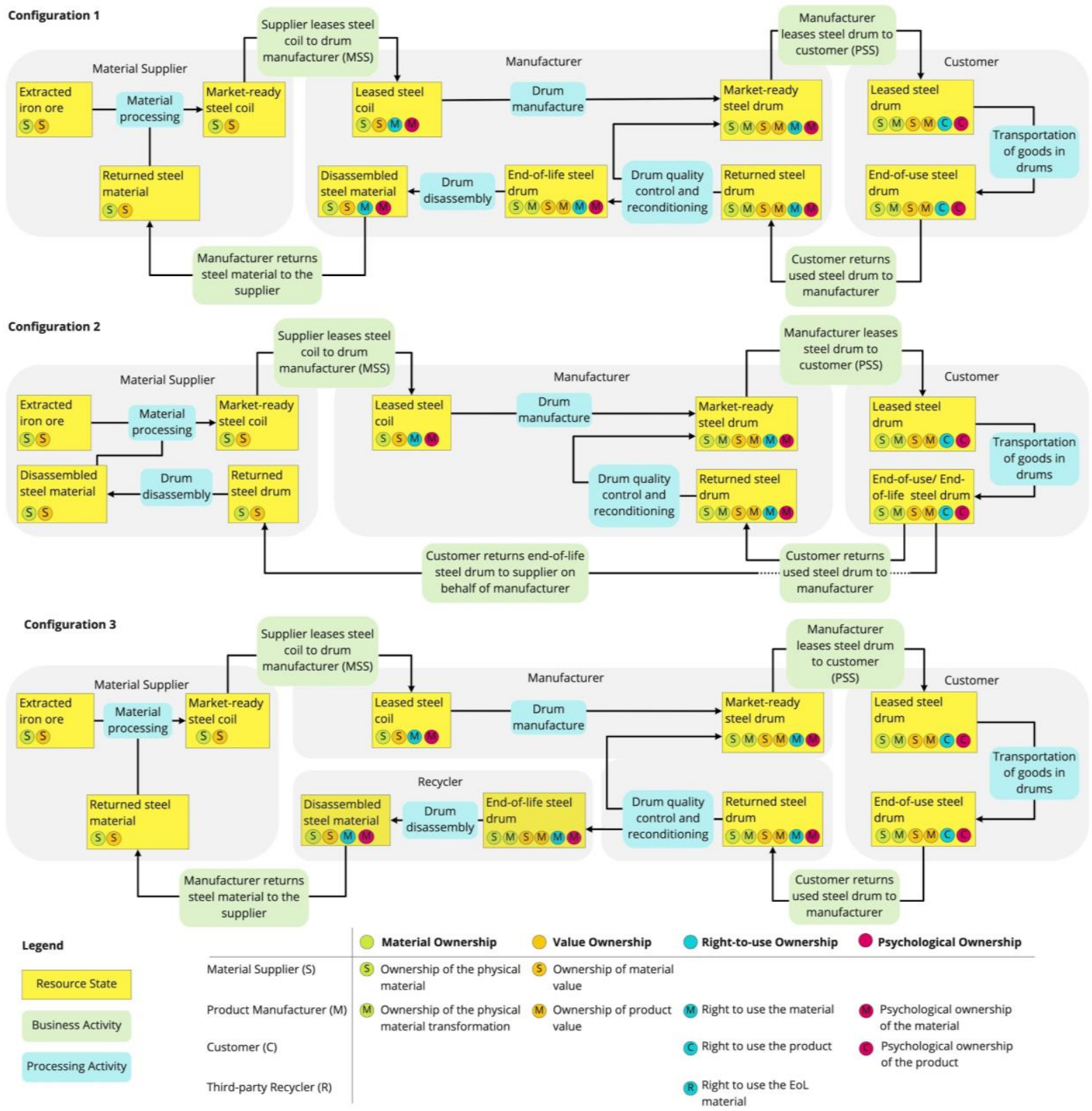

Figure 2. Three supply chain configurations

Forward supply chain. In the three configurations, the forward supply chain is invariant. In all cases, the material supplier buys extracted iron ore and processes it into market-ready steel coils. Then, using the MSS, the material supplier leases the value of the coils to the manufacturer who acquires the right to use them, while ownership of the material and the material liabilities remain with the supplier (see Figure 2). At this point, the manufacturer transforms the steel coils into market-ready steel drums, thereby taking ownership of the material transformations, the value added to the product and the product liabilities (see Figure 2). Subsequently, the manufacturer leases steel drums through a PSS to the customer who acquires the right to use them and the product liabilities related to its use, while ownership of the material transformations and the value added to the product remain with the manufacturer. It is noteworthy that the product asset, owned and controlled by the manufacturer, does not include material ownership, while the product right to use asset, controlled by the customer, retains a structure similar to that of PSSs with the exception of material ownership. The drums then enter operation and at the end of each service rotation, used steel drums are returned to the manufacturer for 
reconditioning as they are part of a reuse system through which the drums circulate between the manufacturer and customer (see Figure 2).

Reverse supply chain. When the steel drums reach the end of life, alternative reverse supply chain configurations are conceivable to drive them towards recycling. Based on the service systems discussed in the literature, we propose three variants.

In Configuration 1, the reverse supply chain comprises two separate loops. The first loop, based on existing industrial implementations, consists of the reuse system with the PSS in which the customer returns the drums to the manufacturer. In the second loop, when the drums have reached their end of life, the manufacturer disassembles them and returns the leased materials to the supplier. In Configuration 2, the reverse supply chain comprises a single loop. When the drums have reached their end of life, the customer returns them directly to the supplier, who disassembles them and recovers the leased materials. This increases the speed of the reverse supply chain. In this configuration, the leasing contract between the supplier and the manufacturer ends upon the supplier's receipt of the leased material. In Configuration 3, the reverse supply chain comprises two loops. The first loop is as that in Configuration 1. In the second loop, when the drums have reached their end of life, the manufacturer sends them to the recycler who disassembles the drums and returns the leased materials to the supplier. In order to determine the supply chain best suited for steel industrial drums under the MSS, the three configurations are now assessed using the four attributes in Table 3.

Table 3. Assessment of the three Configurations

\begin{tabular}{|c|c|c|c|}
\hline Attribute & $\begin{array}{l}\text { Supply chain with } \\
\text { Configuration } 1\end{array}$ & $\begin{array}{l}\text { Supply chain with } \\
\text { Configuration } 2\end{array}$ & $\begin{array}{l}\text { Supply chain with } \\
\text { Configuration } 3\end{array}$ \\
\hline $\begin{array}{l}\text { Timeframe of } \\
\text { reverse logistics }\end{array}$ & $\begin{array}{l}\text { Resource passes through } \\
\text { one stakeholder before it } \\
\text { is returned to the material } \\
\text { supplier. }\end{array}$ & $\begin{array}{l}\text { Resource is returned } \\
\text { directly to the material } \\
\text { supplier. }\end{array}$ & $\begin{array}{l}\text { Resource passes through } \\
\text { two stakeholders before it } \\
\text { is returned to the material } \\
\text { supplier. }\end{array}$ \\
\hline $\begin{array}{l}\text { Ease of reverse } \\
\text { logistics } \\
\text { implementation }\end{array}$ & $\begin{array}{l}\text { Existing PSS facilitates } \\
\text { implementation due to } \\
\text { the system being in place } \\
\text { for customers to return } \\
\text { products to the } \\
\text { manufacturer. }\end{array}$ & $\begin{array}{l}\text { Infrastructure required } \\
\text { to allow customers to } \\
\text { return products directly } \\
\text { to the material supplier. }\end{array}$ & $\begin{array}{l}\text { A third-party company } \\
\text { for managing reverse } \\
\text { logistics is needed to } \\
\text { facilitate the material } \\
\text { recovery from the } \\
\text { customers. }\end{array}$ \\
\hline $\begin{array}{l}\text { Number of } \\
\text { material } \\
\text { suppliers that } \\
\text { can be served }\end{array}$ & $\begin{array}{l}\text { Ability to serve multiple } \\
\text { material suppliers } \\
\text { through manufacturer } \\
\text { disassembly. }\end{array}$ & $\begin{array}{l}\text { Limited to a single } \\
\text { supplier as products are } \\
\text { returned directly to the } \\
\text { material supplier for } \\
\text { disassembly and } \\
\text { recovery. }\end{array}$ & $\begin{array}{l}\text { Ability to serve multiple } \\
\text { material suppliers } \\
\text { through third-party } \\
\text { company disassembly } \\
\text { and return. }\end{array}$ \\
\hline $\begin{array}{l}\text { Disassembly } \\
\text { and return } \\
\text { operations }\end{array}$ & $\begin{array}{l}\text { The responsibility for } \\
\text { disassembling products } \\
\text { and returning materials to } \\
\text { their respective suppliers } \\
\text { to end leasing contracts is } \\
\text { on the stakeholder with } \\
\text { the greatest knowledge of } \\
\text { the product, i.e. the } \\
\text { manufacturer. }\end{array}$ & $\begin{array}{l}\text { The responsibility for } \\
\text { disassembling products } \\
\text { is on a stakeholder } \\
\text { without comprehensive } \\
\text { knowledge of the } \\
\text { product, i.e. the material } \\
\text { supplier. }\end{array}$ & $\begin{array}{l}\text { The responsibility for } \\
\text { disassembling products } \\
\text { and returning materials to } \\
\text { their respective suppliers } \\
\text { is on a third party, which } \\
\text { may not have extensive } \\
\text { knowledge of products. } \\
\text { The manufacturer may } \\
\text { still be involved in } \\
\text { returning materials to } \\
\text { their respective suppliers. }\end{array}$ \\
\hline
\end{tabular}

The attributes should be interpreted as criteria to serve a supply chain based on the MSS. Steel drums are produced through the forming and welding of steel sheets. Given that the drums are mono-material 
and have a relatively simple geometry, Configuration 2, compared to Configurations 1 and 3, offers the advantage that the drums are returned directly to the material supplier which accelerates the recovery. Although the material supplier does not typically have disassembly capabilities, upholding this responsibility is considered acceptable in this case due to the low complexity of steel drums. However, the lack of infrastructure in place for customers to return the drums directly to the material supplier is an issue that requires attention. Moreover, if a steel drum supply chain is global, the MSS would lead to a long reverse supply chain. Given that virgin and scrap steels are traded globally, a long reverse supply chain is considered acceptable though the preference would be to retain steel on local economies as much as possible.

\section{DISCUSSION}

This research has traced the evolution of service systems other than PSSs, contributing to the consolidation of literature related to services. It has also advanced current understandings of the MSS model by explaining how resources flow in the supply chain and how ownership is split between stakeholders.

The benefits and challenges of the MSS model have been reported in Section 2.2 and in (Aurisicchio et al., 2020). A key barrier to introducing the MSS is the cultural and political shift required to make product manufacturers accept psychological rather than physical ownership of materials. In particular, the research shows that if a product manufacturer were to operate under this system, it would lease the value of materials from a supplier but own the material transformations undertaken to produce the final product along with the value added and the product liabilities. The breakdown of ownership proposed in Table 2 and exemplified in the case study is an important step to develop the business model.

A highly recyclable material such as the steel used to make durable and reusable drums was found to be an interesting application for the MSS. First, the MSS is expected to stimulate the manufacturer to design drums that can be easily maintained, repaired, refurbished and recycled (Aurisicchio et al., 2020) thereby extending the drums lifetime, slowing down the consumption flow and minimising energy usage in the supply chain. Second, retained ownership of the materials by the supplier is expected instead to encourage investments in durable and recyclable alloys as the supplier will have certainty that the resources are returned to them. Overall, it seems that the MSS can co-exist rather than compete with business models to flow resources at a higher utility such as reuse.

Finally, the research shows how a supply chain adopting the MSS can be structured and operated. Three alternative reverse supply chains have been explored, identifying factors that contribute to circular success and showing which configuration is the most promising for steel drums due to their characteristics.

The main limitation of this research is that a mono-material and simple product was selected to begin the investigation of the MSS business model. More work is needed to investigate the challenges posed by multi-material and more complex products. In addition, although the case study is largely based on data from real-world supply chains offering reusable industrial drums with reconditioning services, part of the data is hypothetical as the MSS business model does not exist yet.

\section{CONCLUSIONS}

Shifting towards a CE requires efficient resource management. PSSs are business models that centralise ownership of resources in the hands of manufacturers or service providers, incentivising them to prevent losses and waste. MSSs, meanwhile, are business models that offer materials as a service and incentivise material suppliers to make a more efficient use of resources. Using the case of steel industrial drums, this paper extends previous discussions of the MSS model by providing a detailed account of the states of a resource, how resources move and are transformed, and which stakeholder owns the materials, the values added, the rights to use and the liabilities.

\section{ACKNOWLEDGEMENTS}

The authors acknowledge the support for this research from the Imperial College London Undergraduate Research Opportunities Programme (UROP) and the EPSRC Vacation Award 2020. 


\section{REFERENCES}

Aurisicchio, M., Zeeuw van der Laan, A. and Tennant, M. (2020) 'Material-Service Systems for Sustainable Resource Management', EcoDesign and Sustainability, Vol. I, pp. 89-101.

Baxter, W.L. and Aurisicchio, M. (2018) 'Ownership by Design', in Peck, J. and Shu, S. (Eds.), Psychological Ownership and Consumer Behavior, Springer, Cham, pp. 119-134.

Blomsma, F., Kjaer, L., Pigosso, D., McAloone, T.C. and Lloyd, S. (2018) 'Exploring Circular Strategy Combinations - towards Understanding the Role of PSS', Procedia CIRP, The Author(s), Vol. 69, pp. 752-757.

Blomsma, F. and Tennant, M. (2020a) 'Circular economy: Preserving particles or products? Introducing the Resource States framework', Resources, Conservation and Recycling, Vol 156.

Blomsma, F., Tennant, M. and Brennan, G. (2020b) 'Beyond Product / Service Systems - towards a system view of circular strategies, circular business models, and circular value chains', IS4CE2020 Conference of the International Society for the Circular Economy.

Brunner, P. H. and Rechberger, H. (2004) 'Practical Handbook of Material Flow Analysis', Lewis Publishers, Boca Raton, FL.

Ellen MacArthur Foundation. (2012) 'Towards the Circular Economy (Volume 1): Economic and Business Rationale for an Accelerated Transition', Ellen MacArthur Foundation.

Ellen MacArthur Foundation. (2020) 'The Circular Economy in Detail', available at: https://www.ellenmacarthurfoundation.org/explore/the-circular-economy-in-detail (accessed 11 December 2020.

Hagan, A.J., Tost, M., Inderwildi, O.R., Hitch, M. and Moser, P. (2019) 'The license to mine making resource wealth work for those who need it most', Resources Policy, Elsevier Ltd, Vol. 5.

Manuilova, A. (2003), Life Cycle Assessment of Industrial Packaging for Chemicals, Master thesis, Chalmers University of Technology.

Ness, D., Swift, J., Ranasinghe, D.C., Xing, K. and Soebarto, V. (2015) 'Smart steel: New paradigms for the reuse of steel enabled by digital tracking and modelling', Journal of Cleaner Production, Elsevier Ltd, Vol. 98, pp. 292-303.

Stahel, W.R. (2010) The Performance Economy, 2nd ed., Palgrave Macmillan, Basingstoke.

Stahel, W.R. (2019a) The Circular Economy: A User's Guide, 1st ed., Routledge, London.

Stahel, W.R. (2019b) 'Innovation in the circular and the performance economy', Handbook of Sustainable Innovation, Edward Elgar Publishing.

Stahel, W.R. and Clift, R. (2016) 'Stocks and Flows in the Performance Economy', in Clift, R. and Druckman, A. (Eds.), Taking Stock of Industrial Ecology, Springer, Cham, pp. 1-362.

Stark, J. (2011) Product Lifecycle Management: 21 st Century Paradigm for Product Realisation, 2nd ed., Springer.

Stoughton, M. and Votta, T. (2003) 'Implementing service-based chemical procurement: lessons and results', Journal of Cleaner Production, Elsevier, Vol. 11, No. 8, pp. 839-849.

The Industrial Packaging Association (IPA). (2020) 'Steel Drums', available at: http://www.theipa.co.uk/steeldrums (accessed 11 December 2020).

Torres de Miranda Pinto, J. (2019a) Sustainable Resource Management in European Steel Supply Chains, PhD thesis, Université Clermont Auvergne.

Torres de Miranda Pinto, J. (2019b) 'The 'circularity paradox' in the European steel industry', The Conversation, available at: https://theconversation.com/the-circularity-paradox-in-the-european-steelindustry-125613 (accessed 11 December 2020).

Tukker, A. (2004) 'Eight types of product-service system: Eight ways to sustainability? Experiences from suspronet', Business Strategy and the Environment, Vol. 13, No. 4, pp. 246-260.

United Nations Environment Programme (UNEP). (2015) 'Using Product-Service Systems to Enhance Sustainable Public Procurement', May, UNEP.

United Nations Industrial Development Organisation (UNIDO). (2016) Global Promotion and Implementation of Chemical Leasing Business Models in Industry, UNIDO, Vienna.

van Ewijk, S. (2018) Resource Efficiency and the Circular Economy Concepts, Economic Benefits, Barriers, and Policies, Report for the Department for Environment, Food \& Rural Affairs (Defra).

World Steel Association (WSA). (2015) Steel in the Circular Economy. A Life Cycle Perspective.

Zeeuw van der Laan, A. and Aurisicchio, M. (2020) 'A framework to use product-service systems as plans to produce closed-loop resource flows', Journal of Cleaner Production, Vol. 252. 